\title{
Factors Affecting Technical Efficiency of Rubber Smallholders in Negeri Sembilan, Malaysia
}

\author{
A. Aliyu ${ }^{1}$, Ismail Abd Latif ${ }^{1}$, Mad Nasir Shamsudin $^{1} \&$ Nolila Mohd Nawi ${ }^{1}$ \\ ${ }^{1}$ Department of Agribusiness and Bio resource Economics, Faculty of Agriculture, Universiti Putra Malaysia, \\ Serdang, Selangor, Malaysia \\ Correspondence: A. Aliyu, Department of Agribusiness and Bio resource Economics, Faculty of Agriculture, \\ Universiti Putra Malaysia, Serdang, Selangor 43400, Malaysia. E-mail: abdualiyu14@ymail.com
}

Received: November 21, 2016

Accepted: March 30, $2017 \quad$ Online Published: April 15, 2017

doi:10.5539/jas.v9n5p226

URL: https://doi.org/10.5539/jas.v9n5p226

\begin{abstract}
The main objective of the study was to figure out, identify and analyse the technical efficiency of rubber smallholders' production in Negeri Sembilan, Malaysia. Multi-stage data collection procedures, comprising both purposive and random sampling techniques, were used. Using structured questionnaires, farm-level information with cross sectional data from five districts of Negeri Sembilan, were employed in the study. A parametric Stochastic Frontier Analysis (SFA), with a transcendental logarithmic (Translog) functional form, was used in the study. The descriptive statistics results revealed that, the mean rubber yield was $5465 \mathrm{~kg}$ while that of the seven inputs used include $1.2 \mathrm{ha}, 602.7,2.33,363.6 \mathrm{~kg}, 13.0$ lit, 13.2 man days and 2.47 respectively for farm size, task, farm tools, fertilizer, herbicides, labour and rubber clones. The inferential statistics showed that, the mean technical efficiency was found to be 0.73 with a standard deviation of 0.089 . Thus, this translates that $27 \%$ accounted for technical inefficiency. Both the sigma square and gamma coefficients were found to be statistically significant at $1 \%$ level. The Log Likelihood Function (LLF) and the Log Rati (LR) test were found to be respectively 167.7 and 34.07. The results further revealed that, although none of the farms were found to be on the frontier, however, 9 farms were very near the frontier with efficiency score range between 0.90-0.99. And twenty (20) firms have range 0.80-0.90. Race, Tapping experience, household number and extension agent's visits were found to be technically significant and are thus critical in determining technical efficiency of rubber smallholders in Negeri Sembilan, Malaysia.
\end{abstract}

Keywords: technical efficiency, stochastic frontier analysis, transcendental logarithmic, smallholders, Negeri Sembilan

\section{Introduction}

Previous research studies such as Tyler and Lee (1979), Tayler and Shonkwiller (1986), Battese and Corra (1977), Battese and Coelli $(1993,1995,1998)$, etc. have unanimously aggreed that the use of stochastic frontier analysis (SFA) technique was originated from the work of Aigner, Lovelle, and Schmidt (1977; Meesun \& Vanden Broeck, 1977). The technique has been lagely used in a pool of literatures of studies of cost, revenue, production, profits and other models.

Recent proposal of the model by Battese and Coelli (1995) can be mathematically expressed as shown below,

$$
Y_{i}=f\left(x_{\mathrm{i}}, \beta\right) \exp \left(v_{i}-u_{i}\right)
$$

Where, $Y_{i}$ denotes the rubber yield of farm; $x_{i}$ signifies the input vector used in the production process; $\beta$ represents the parameters of the input vector to be estimated; $v_{i}$ stands as the measurement error or random variable that is half-normally, identically and independently distributed with a mean zero and variance $\partial^{2}[\mathrm{~N}(0, \tilde{\mathrm{o}})]$; $u_{i}$ is a non-negative random variable or statistical noise capable of influencing the shape and positions of the production frontier and is associated with the technical inefficiency during the production process (Iliyasu et al., 2014; Msuya, 2008) which also assumed by Aigner et al. (1977) as Identically independently distributed with mean zero and variance ${ }^{2}[\mathrm{~N}(0, \tilde{\mathrm{o}})]$.

The disturbance $\left(v_{i}-u_{i}\right)$ is often termed composite error term and as suggested earlier, it can be used to measure both the random shocks as well as inefficiency. 


\section{Review of Related Literatures on Technical Efficiency on Rubber Farms}

Giroh et al. (2012) investigated the factors militating against technical efficiency of women rubber tappers in Nigeria. The study covered 60 women rubber tappers and was carried out in rubber research institute of Nigeria, Iyamo Benin City, Nigeria. The findings of the study revealed both the descriptive and inferential statistical results. The descriptive statistics which covers the mean age, number of trees tapped per hectare as well as average annual output were revealed as 33 years, 326 trees/ha and $2723 \mathrm{~kg}$ of dry rubber respectively. The inferential statistics looked at regression analysis of the relationship between technical efficiency scores and various factors influencing technical efficiency.

Giroh and Adebayo (2007) used SFA in conducting a study to analyse TE of rubber tapping in Nigeria. The study used 129 respondents on the basis of the tenure of their appointments, in which 68 were drawn from permanent and 61 from non-permanent. The maximum likelihood estimates (MLE) of the analysis revealed that the variance parameters such as gamma $(\gamma)$ and Sigma squared $\left(\delta^{2}\right)$ were statistically significant and had positive coefficients of 0.96 and 0.011 respectively. While the sigma squared $\left(\delta^{2}\right)$ indicated goodness of fit and correctness of the model, the parameter gamma indicated the dominant source of random error which was unexplained by the production function. The study also disclosed that of all the 4 explanatory variables, only wage and plantation's age were statistically significant. The positive and statistically significant wage variable has a coefficient estimate of 1.09 while that of the plantation's age was 4.19. Thus it's suggested that more wages and young plantations leads to enhanced technical efficiency of rubber tapping in Nigeria.

Similar study conducted by Giroh and Adebayo (2009) in analysing technical inefficiency of rubber tapping in rubber research institute of Nigeria (RRIN) using SFA, published in journal of human ecology. The study revealed that the mean or average technical efficiency score of the rubber tappers was 0.72 . This means that it is technically inefficient because it produces below the production frontier and thus has a gap of $28 \%$ to be technically efficient. The study further revealed that the technical efficiency scores for the least and best practice rubber tappers, were $0.38(38 \%)$ and $0.99(99 \%)$ respectively.

Maximum Likelihood Estimation (MLE) method of Cobb-Douglas production, under Stochastic Frontier Analysis (SFA) approach, was used in a study conducted in Edo and Delta states. The study specifically carried out to analyse the efficiency of latex productions in rubber plantations in Edo and Delta states, Nigeria (Giroh, Adebayo, \& Jongur, 2013). The study used 300 rubber farms using purposive random sampling techniques. The findings of the study reported both the mean technical and allocative efficiency scores as 0.84 and 0.77 respectively. The findings also disclosed that the variance parameters such as Sigma Squared, Gamma and Log Likelihood Function (LLF) are 0.822, 0.923 and -0.702 respectively.

Alias et al. (2012) has conducted an empirical survey in Malaysia, using stochastic frontier analysis. The study analysed technical efficiency of manufactured rubber product industries across the country. 313 firms that manufacture rubber products were generated from annual surveys of industries by Malaysian Statistics Department in 2004. The mean technical efficiency was found to be $0.7033(70.3 \%)$. It was also observed that only $10 \%$ of the firms (about 34 farms) have technical efficiency scores more than $80 \%$.

The study further revealed that all the coefficients of capital, labour and energy were found to be statistically significant at 1\% level, under both the Ordinary Least Squares (OLS) and the Maximum Likelihood Estimation (MLE) methods. The signs on the coefficients were all positives, and this indicates that an increase in one unit of variable inputs, leads to an increase in output. The coefficient of determination $\left(\mathrm{R}^{2}\right)$ was found to be 0.88 or $88 \%$. This specifically indicates that $88 \%$ of the variations in the dependent variable are explained by the variations in the independent variables.

Mustapha (2011) also used a parametric SFA and empirically examined the relative performance of Rubber Industry Smallholders Development Authority (RISDA) supervised rubber smallholders in besut district of Terengganu, Malaysia.

The study, which used both the Cobb-Douglas (CD) and Translog (TL) production frontiers, composed of 35 rubber smallholders and only two inputs were used during the analysis in besut district.Thus, two different technical efficiency measures were obtained under the two different production functions of CD and TL. The mean technical efficiency scores were reported to be 0.832 and 0.817 for Cobb-Douglas and Translog production functions respectively. The findings also revealed that, highest percentage of farms (about $48.7 \%$ of the total farms) under investigation, scored above average of 0.80 . While only $8.6 \%$ of the total farms scoring below average and is in the lowest category of 0.60-0.65 technical efficiency scores. 
The influence of sociological factors and some management proxies on productivity of rubber smallholders in Malaysia was investigated by (Sapien, 1979), using Pearson Correlation analysis as an analytical technique obtained in statistical packages for social sciences (SPSS). The study used 324 smallholder farms with 185 un-assisted (idependent) and 149 fully government-assisted smallholders in Melaka, peninsular Malaysia in 1979. Four selected management proxies and twelve sociological factors were drawn and included in the analysis, to test for significance association between the various factors and dry rubber content (output per hecter).

The findings of the study were discussed under two headings and three subheadings. The two headings are sociological factors and management proxies, while the three subheadings include the pooled data, Federal Land Development Authority (FELDA) smallholders and independent smallholders. Specifically, matrix of correlations of yield, Management proxies and sociological factors under pooled data, FELDA smallholders and independent smallholders were fully examined.

The findings further revealed that management index and farmers' technical knowledge were positively correlated, which in turn positively associated with rubber yield. Also related to rubber yield under FELDA smallholders, is women's education. However, some drawbacks were also reported. Notable among them include, poor knowledge of management by FELDA smallholders, lack of good contacts with extension agents.

Poungchompu and Chantanop (2005) conducted an investigation to find the productive performance in terms of technical efficiency of Para rubber farms in Thailand. The study targeted or aimed at finding out the major influential factors affecting production output as well as technical efficiency of Para rubber farms in North-Eastern region of Thailand. The result of the study indicated that, both the variance parameter of gamma and sigma squared, were statistically significant at $1 \%$ level. The values were found to be 0.366 and 0.672 for the sigma squared and gamma respectively. The sigma-squared indicates goodness of fit and correctness of distributional form, while the gamma indicates the degree of the residual variation due to efficiency effects.

The findings also reported that the mean technical efficiency was found to be 0.537 and thus it translates that the there was a short fall or lag gap of 0.427 . Hence it's suggested that the technical efficiency of Para rubber could be increased by $42.7 \%$ through effective utilization of the available resources.

An unbalanced panel data of 33 rubber farms in Dong-Nai, Song-Be and Tay-Ninh provinces of South-eastern region of Vietnam were analysed to find technical efficiency of state rubber farms using a time-varying stochastic frontier analysis technique (Tran et al., 1993). The result of the analysis indicated that, the mean technical efficiency score was found to be 0.59 while the Log-Likelihood ratio of the MLE technique was found to be $-9.66,-10.49,-10.24,-11.47$ and -49.25 under five different assumptions test used in the study.

\section{Methodology}

\subsection{Empirical Model Specifications}

In conducting technical efficiency analysis using Stochastic Frontier Production technique, three different empirical models or functional forms are often being employed. Such functional forms include Cobb-Douglas, Transcendental Logarithmic and Constant Elasticity of Substitutions (CES) models. Unlike the first two models (i.e. Translog and Cobb-Douglas models), the third model (i.e. CES) has not been so rampant in the literature. Although the two models are frequently been used, but each of them has both advantage as well as some loopholes. For this study, translog production function was adopted and used as shown below.

Transcendental Logarithmic (Translog) Production Functions:

$$
\begin{aligned}
\ln Y_{i}= & \beta_{0}+\beta_{1} \ln x_{i}+\beta_{2} \ln x_{2 i}+\beta_{3} \ln x_{3 i}+\beta_{4} \ln x_{4 i}+\beta_{5} \ln x_{5 i}+\beta_{6} \ln x_{6 i}+\beta_{7} \ln x_{7 i}+\beta_{8}\left(\ln x_{1 i}\right)^{2}+\beta_{8}\left(\ln x_{1 i}\right)^{2}+\beta_{9}\left(\ln x_{2 i}\right)^{2}+ \\
& \beta_{10}\left(\ln x_{3 i}\right)^{2}+\beta_{11}\left(\ln x_{4 i}\right)^{2}+\beta_{12}\left(\ln x_{5 i}\right)^{2}+\beta_{13}\left(\ln x_{6 i}\right)^{2}+\beta_{14}\left(\ln x_{7 i}\right)^{2}+\beta_{15}\left(\ln x_{1 i}\right)\left(\ln x_{2 i}\right)+\beta_{16}\left(\ln x_{1 i}\right)\left(\ln x_{3 i}\right)+\beta_{17}\left(\ln x_{1 i}\right) \\
& \left(\ln x_{4 i}\right)+\beta_{18}\left(\ln x_{1 i}\right)\left(\ln x_{5 i}\right)+\beta_{19}\left(\ln x_{1 i}\right)\left(\ln x_{6 i}\right)+\beta_{20}\left(\ln x_{1 i}\right)\left(\ln x_{7 i}\right)+\beta_{21}\left(\ln x_{2 i}\right)\left(\ln x_{3 i}\right)+\beta_{22}\left(\ln x_{2 i}\right)\left(\ln x_{4 i}\right)+ \\
& \beta_{23}\left(\ln x_{2 i}\right)\left(\ln x_{5 i}\right)+\beta_{24}\left(\ln x_{2 i}\right)\left(\ln x_{6 i}\right)+\beta_{25}\left(\ln x_{2 i}\right)\left(\ln x_{7 i}\right)+\beta_{26}\left(\ln x_{3 i}\right)\left(\ln x_{4 i}\right)+\beta_{27}\left(\ln x_{3 i}\right)\left(\ln x_{5 i}\right)+\beta_{28}\left(\ln x_{3 i}\right)\left(\ln x_{6 i}\right) \\
& +\beta_{29}\left(\ln x_{3 i}\right)\left(\ln x_{7 i}\right)+\beta_{29 n \times 30}\left(\ln x_{4 i}\right)\left(\ln x_{5 i}\right)+\beta_{29 n \times 31}\left(\ln x_{4 i}\right)\left(\ln x_{6 i}\right)+\beta_{29 n x 32}\left(\ln x_{4 i}\right)\left(\ln x_{7 i}\right)+\beta_{29 n \times 33}\left(\ln x_{5 i}\right)\left(\ln x_{6 i}\right)+ \\
& \beta_{29 n x 34}\left(\ln x_{5 i}\right)\left(\ln x_{7 i}\right)+\beta_{29 n x 35}\left(\ln x_{6 i}\right)\left(\ln x_{7 i}\right)+v_{i}-u_{i} \\
& i=1,2,3 \ldots 7
\end{aligned}
$$

Where,

$Y_{i}$ is the output of the $i$ th rubber farm; $x_{1 i}, x_{2 i}, x_{3 i}, x_{4 i}, \ldots x_{35 i}$, are the input variables of the $i$ th farm; $v_{i}$ are random variables assumed to be iid $N\left(0, \delta_{v}{ }^{2}\right)$ and independent of $u_{i} ; u_{i}=\{\exp [-\dot{\eta}(t-T)]\} \varepsilon_{i}, i=1,2,3,4, \ldots 35$, where, the $u_{i}$ are non negative random variables which are assumed to be iid. $\varepsilon_{i}=v_{i}-u_{i}, \varepsilon_{i}$ is a disturbance term; $\beta_{k}$ is an unknown parameter to be estimated, $\mathrm{k}=0,1, \ldots 7 ; \dot{\eta}$ is an unknown scalar parameter to be estimated. 


\subsection{List of Production Inputs Used}

$\mathrm{X}_{1}=$ Tapping Area or land size; $\mathrm{X}_{2}=$ Rubber task; $\mathrm{X}_{3}=$ Farm tools; $\mathrm{X}_{4}=$ Bags of fertilizer; $\mathrm{X}_{5}=$ Chemical Herbicides; $\mathrm{X}_{6}=$ Labor in man days; $\mathrm{X}_{7}=$ Rubber clone; $\mathrm{V}_{\mathrm{i}}=$ Random noise (white noise) which are $\mathrm{N}\left(0, \dot{o}^{2} \mathrm{v}\right)$; $\mathrm{U}_{\mathrm{i}}=$ are inefficiency effects which are non-negative, truncated normal distribution $\mathrm{N}\left(0, \dot{o}^{2} \mathrm{U}\right)$.

\subsection{Determinants of Efficiency Scores}

$Z_{1}=$ Gender; $Z_{2}=$ Race; $Z_{3}=$ Marital Status; $Z_{4}=$ household size (number of persons in the household); $Z_{5}=$ Tapping experience (years); $Z_{6}=$ Education level; $Z_{7}=$ Topography; $Z_{8}=$ Extension Visits; $Z_{9}=$ District/location; $Z_{10}=$ Farmer's Age; $Z_{11}=$ Tapping System; $Z_{12}=$ Farm Distance.

\section{Results and Discussions}

Table 1. Descriptive statistics

\begin{tabular}{llll}
\hline Variables & Descriptive & Mean & Standard Deviation \\
\hline Production Function & & & \\
$\mathrm{Y}$ & Rubber yield (Kg) & 5465 & 3716 \\
$\mathrm{X}_{1}$ & Farm Size (ha) & 1.2 & 0.48 \\
$\mathrm{X}_{2}$ & Rubber task(per ha) & 602.7 & 243.4 \\
$\mathrm{X}_{3}$ & Farm tools (RM) & 2.33 & 1.61 \\
$\mathrm{X}_{4}$ & Fertilizer (Kg/ha) & 363.6 & 188 \\
$\mathrm{X}_{5}$ & Herbicides (lit/ha) & 13.0 & 5.1 \\
$\mathrm{X}_{6}$ & Labour (Mph) & 13.2 & 2.0 \\
$\mathrm{X}_{7}$ & Clone & 2.47 & 0.85 \\
\hline
\end{tabular}

Table 1 above contains the mean and standard deviations of the rubber yield and various inputs used in the transcendental logarithmic (Translog) stochastic frontier production analysis. The mean yield was found to be $5465 \mathrm{~kg} / \mathrm{ha} / \mathrm{year}$ ). The number of rubber tree per ha is 602 while fertilizer, herbicides and labour were found to be $363.6 \mathrm{~kg} / \mathrm{ha} /$ year), $13.0 \mathrm{litre} / \mathrm{ha} /$ year and $13.2 \mathrm{man}$ per hour respectively.

Table 2. Maximum likelihood estimation of the Translog production function

\begin{tabular}{lll|lll}
\hline Variables & Coefficient & T-ratio & Variables & Coefficient & T-ratio \\
\hline Constant & 17.102 & 0.796 & $\ln \mathrm{X}_{1} \ln \mathrm{X}_{2}$ & -0.705 & $(-1.160)$ \\
$\ln \mathrm{X}_{1}$ & 1.844 & 1.227 & $\ln \mathrm{X}_{1} \ln \mathrm{X}_{3}$ & 0.417 & $(0.623)$ \\
$\ln \mathrm{X}_{2}$ & -13.187 & $(-2.239)^{* * *}$ & $\ln \mathrm{X}_{1} \ln \mathrm{X}_{4}$ & -0.168 & $(-1.966)^{* *}$ \\
$\ln \mathrm{X}_{3}$ & -3.108 & -0.710 & $\ln \mathrm{X}_{1} \ln \mathrm{X}_{5}$ & 2.058 & $(2.037)^{* * *}$ \\
$\ln \mathrm{X}_{4}$ & 4.513 & $(2.765)^{* * *}$ & $\ln \mathrm{X}_{1} \ln \mathrm{X}_{6}$ & 1.685 & $(0.674)$ \\
$\ln \mathrm{X}_{5}$ & -6.809 & $(-3.217)^{* * *}$ & $\ln \mathrm{X}_{1} \ln \mathrm{X}_{7}$ & 0.720 & $(1.040)$ \\
$\ln \mathrm{X}_{6}$ & 4.293 & 0.192 & $\ln \mathrm{X}_{2} \ln \mathrm{X}_{3}$ & 0.966 & $(0.631)$ \\
$\ln \mathrm{X}_{7}$ & 0.429 & 0.104 & $\ln \mathrm{X}_{2} \ln \mathrm{X}_{4}$ & 0.104 & $(0.106) \mathrm{NS}$ \\
$\left(\ln \mathrm{X}_{1}\right)^{2}$ & -1.571 & $(-3.443)^{* * *}$ & $\ln \mathrm{X}_{2} \ln \mathrm{X}_{5}$ & 0.001 & $(0.002) \mathrm{NS}$ \\
$\left(\ln \mathrm{X}_{2}\right)^{2}$ & 0.877 & $(2.066)^{* *}$ & $\ln \mathrm{X}_{2} \ln \mathrm{X}_{6}$ & 6.854 & $(1.052) \mathrm{NS}$ \\
$\left(\ln \mathrm{X}_{3}\right)^{2}$ & -2.808 & $(-7.626)^{* * *}$ & $\ln \mathrm{X}_{2} \ln \mathrm{X}_{7}$ & 3.173 & $(3.176)^{* * *}$ \\
$\left(\ln \mathrm{X}_{4}\right)^{2}$ & -0.214 & -0.393 & $\ln \mathrm{X}_{3} \ln \mathrm{X}_{4}$ & 0.231 & $(0.298) \mathrm{NS}$ \\
$\left(\ln \mathrm{X}_{5}\right)^{2}$ & -0.959 & -1.945 & $\ln \mathrm{X}_{3} \ln \mathrm{X}_{5}$ & 0.724 & $(1.312)$ \\
$\left(\ln \mathrm{X}_{6}\right)^{2}$ & -9.974 & $(-4.960)^{* * *}$ & $\ln \mathrm{X}_{3} \ln \mathrm{X}_{6}$ & 0.696 & $(0.491) \mathrm{NS}$ \\
$\left(\ln \mathrm{X}_{7}\right)^{2}$ & -3.546 & $(-6.136)^{* * *}$ & $\ln \mathrm{X}_{3} \ln \mathrm{X}_{7}$ & -0.709 & $(-1.534)^{*}$ \\
$\ln \mathrm{X}_{4} \ln \mathrm{X}_{5}$ & 0.275 & $(0.441) \mathrm{NS}$ & $\ln \mathrm{X}_{4} \ln \mathrm{X}_{6}$ & -2.975 & $(-2.767)^{* * *}$ \\
$\ln \mathrm{X}_{4} \ln \mathrm{X}_{7}$ & -1.828 & $(3.509)^{* * *}$ & $\ln \mathrm{X}_{5} \ln \mathrm{X}_{6}$ & 6.937 & $(5.216)^{* * *}$ \\
$\ln \mathrm{X}_{5} \ln \mathrm{X}_{7}$ & -0.704 & $(-1.210) \mathrm{NS}$ & $\ln \mathrm{X}_{6} \ln \mathrm{X}_{7}$ & -1.614 & $(-0.598) \mathrm{NS}$ \\
\hline
\end{tabular}

Source: Field survey, 2015. 
Table 2 captures the results of maximum likelihood estimates (MLE), Inefficiency model and variance parameters of Translog stochastic frontier production model of rubber smallholder farms.

Although the production inputs used was seven independent variables, but in using Translog production function model, each of the input variables were squared and the variables were then interacted with one another in line with the transcendental logarithmic production model.

Therefore, having squared each of the independent variables and interacted with one another, the combined variables now became 35 and this formed the independent variables used in the Translog production frontier model. The number of observations remained 206.

Added to the 35 variables during the analysis were 12 numbers of factors determining inefficiency. All the 12 variables were socio-demographic variables. It was observed that out of 35 independent variables, 16 were found to be statistically significant. 14 were statistically different from zero at $1 \%$ significance level, one was found to be significant at $5 \%$, while the remaining one was significant at $10 \%$ level of significance.

Out of the 16 statistically significant variables, three are from the core inputs, six were squared variables and seven were interactive variables. Summarily, we can say that more than $50 \%$ of the variables were found to be statistically significant.

Table 3. Determinants of technical efficiency

\begin{tabular}{lll}
\hline Determinants & Coefficient & T-ratio \\
\hline Gender $\left(Z_{1}\right)$ & -0.023 & $(-1.065) \mathrm{NS}$ \\
Race $\left(\mathrm{Z}_{2}\right)$ & 0.032 & $(2.989)^{* * *}$ \\
Marital Status $\left(\mathrm{Z}_{3}\right)$ & 0.009 & $(0.190) \mathrm{NS}$ \\
House Hold $\left(\mathrm{Z}_{4}\right)$ & -0.012 & $(-1.919)^{* *}$ \\
Tapping Experience $\left(\mathrm{Z}_{5}\right)$ & 0.001 & $(2.354)^{* * *}$ \\
Level of Education $\left(\mathrm{Z}_{6}\right)$ & -0.005 & $(-0.305) \mathrm{NS}$ \\
Topography $\left(\mathrm{Z}_{7}\right)$ & -0.007 & $(-0.348) \mathrm{NS}$ \\
Extension Visits $\left(\mathrm{Z}_{8}\right)$ & -0.546 & $(-2.585)^{* * *}$ \\
Districts $\left(\mathrm{Z}_{9}\right)$ & 0.022 & $(0.850) \mathrm{NS}$ \\
Tapping system $\left(\mathrm{Z}_{10}\right)$ & 0.022 & $(0.609) \mathrm{NS}$ \\
Farmer's Age $\left(\mathrm{Z}_{11}\right)$ & -0.002 & $(-1.215) \mathrm{NS}$ \\
Farm Distance $\left(\mathrm{Z}_{12}\right)$ & 0.0001 & $(0.014) \mathrm{NS}$ \\
Sigma square $\left(\delta^{2}\right)$ & 0.01167 & $(9.710)^{* * *}$ \\
Gamma $(\gamma)$ & 1.000 & $(9.1091)^{* * *}$ \\
\hline LLF $=167.66$ & LR test $=34.07$ & Mean T.E. $=0.726$ \\
\hline
\end{tabular}

Source: Field survey, 2015.

The variance parameter such as sigma squared and gamma were both found to be statistically significant at $1 \%$ level of significance. This sigma squared is indicating a goodness of fit of the Translog production model, while gamma value is indicating that the error term was normally distributed.

The log likelihood ratio test was found to be 34.07 while the LLF was 167.66.

The mean technical efficiency was found to be $0.73(73 \%)$ and thus less than its counterpart value of 0.77 in Cobb Douglas production function model.

The twelve socio-demographic variables added to the 35 independent variables were also analysed. The results indicated that four of the determinants were statistically different from zero at $1 \%$ level of significance. These four include race, household size, tapping experience and extension visits.

Two of them were found to be critical in determining the efficiency of the rubber smallholder farms. The two critical determinants are number of household and extension visits. This means that when the number of house hold increases, more of the rubber latex would be extracted (tapped).

The number of extension visits was also found to be very critical in determining the yield of rubber latex. This is also in conformity with a priori expectations. This translates that, high and frequent number of visits paid to the smallholder farmers by the extension agents (in this regards RISDA personnel), helps to educate farmers on new 
and improved technology. Such technologies might be fertilizer application, use of rubber tapping machine and other general agricultural practices.

Table 4. Range and frequency distributions of efficiency scores

\begin{tabular}{lll}
\hline T.E. Range & Frequency & Percentage \\
\hline Less than 0.20 & 0 & 0.00 \\
$0.21-0.30$ & 0 & 0.00 \\
$0.31-0.40$ & 0 & 0.00 \\
$0.41-0.50$ & 1 & 0.49 \\
$0.51-0.60$ & 11 & 5.34 \\
$0.61-0.70$ & 72 & 34.95 \\
$0.71-0.80$ & 92 & 44.66 \\
$0.81-0.90$ & 20 & 9.71 \\
$0.91-0.99$ & 9 & 4.85 \\
1.00 & 1 & 0.49 \\
Mean & 0.73 & \\
St.dev & 0.089 & \\
Minimum & 0.45 & \\
Maximum & 1.00 & \\
\hline
\end{tabular}

Source: Field survery, 2015.

Table 4 reports the range, frequency distribution and percentages scores of the rubber smallholder farms of Matured-Age category with 206 numbers of observations (farms).

The results revealed that although the mean (average) was $73 \%$, but only one of the farms was found to be technically efficient. That is all the 206 farms analysed have efficient scores less than 1 except one firm and this has only $0.5 \%$ of total firm.

However, about 9 farms were reported to have a range scores between $0.9-0.99$ but this is just $4.4 \%$ of the total number of farms. Large numbers of farms have scores between $0.61-0.80$, and this composed about $80 \%$ of the farms which constituted almost 164 smallholder farms. The results also revealed that only 12 farms were found to have efficiency scores less than 0.5 and this constitute about $6 \%$ of the total number of smallholder farms.

\section{Conclusion}

The paper provides the technical efficiency of rubber smallholders in Negeri Sembilan and their determiners using SFA with a Translog production functional form. It was found out that the average TE was 0.73 . This translates that $23 \%$ of the farms were technically inefficient. Although 29 out of the 206 farms were having efficiency scores more than 0.8 , but no single farm was found to be fully technically efficient. Number of household, years of experience of the farmer, Frequency of the extension agent's visit to impact knowledge on improved technology are critical factors that have great influence on the productivity and technical efficiency of the smallholders in that area.

\section{References}

Aigner, D., Lovell, C. K., \& Schmidt, P. (1977). Formulation and estimation of stochastic frontier production function models. Journal of Econometrics, 6(1), 21-37. https://doi.org/10.1016/0304-4076(77)90052-5

Alias, R., Ahali, N. M., \& Baharoon, A. H. (2012). Technical Efficiency of manufactured rubber products in Malaysia: stochastic frontier Analysis. Elixir. Prod. Mgmt., 42, 6466-6471.

Battese, G. E. (1992). Frontier production functions and technical efficiency: A survey of empirical applications in agricultural economics. Agricultural Economics, 7(3), 185-208. https://doi.org/10.1016/0169-5150(92)90 049-5

Battese, G. E., \& Coelli, T. J. (1988). Prediction of firm-level technical efficiencies with a generalized frontier production function and panel data. Journal of Econometrics, 38(3), 387-399. https://doi.org/10.1016/ 0304-4076(88)90053-X 
Battese, G. E., \& Coelli, T. J. (1993). A stochastic frontier production function incorporating a model for technical inefficiency effects (Vol. 69). Armidale: Department of Econometrics, University of New England.

Battese, G. E., \& Coelli, T. J. (1995). A model for technical inefficiency effects in a stochastic frontier production function for panel data. Empirical Economics, 20(2), 325-332. https://doi.org/10.1007/BF012 05442

Battese, G. E., \& Corra, G. S. (1977). Estimation of a production frontier model: With application to the pastoral zone of Eastern Australia. Australian Journal of Agricultural Economics, 21(3), 169-179. https://doi.org/ $10.1111 /$ j. 1467-8489.1977

Giroh, D. Y., \& Adebayo, E. F. (2007). Analyzing the Technical efficiency of Rubber tapping in Nigeria. Journal of Agriculture and Social Sciences (Pakistan).

Giroh, D. Y., \& Adebayo, E. F. (2009). Analysis of technical inefficiency of rubber tapping in rubber research institute of Nigeria, Benin City, Nigeria. J Hum Ecol, 27(3), 171-174.

Giroh, D. Y., Adebayo, E. F., \& Jongur, A. A. U. (2013). Analysis of labour productivity and constraints of rubber latex exploitation among smallholder rubber farmers in the Niger delta region of Nigeria. Glob J Agr Res, 1, 16-26.

Giroh, D. Y., Moses, J. D., Balogun, F. E., \& Odekina, F. O. (2012). Analysis of the factors influencing the technical efficiency of women rubber tappers in the rubber belt of Nigeria. Gender \& Behaviour, 10(2), 4678-4686.

Hjalmarsson, L., \& Meeusen, W. (1980). Mien van den broek. Journal of Econometrics Specifications and Estimation of Frontier Production, Profit and Cost Functions, 13, 117-138.

Iliyasu, A., Mohamed, Z. A., Ismail, M. M., Amin, A. M., \& Mazuki, H. (2016). Technical efficiency of cage fish farming in Peninsular Malaysia: A stochastic frontier production approach. Aquaculture Research, 47(1), 101-113. https://doi.org/10.1111/are.12474

Meeusen, W., \& Van den Broeck, J. (1977). Efficiency estimation from Cobb-Douglas production functions with composed error. International Economic Review, 18(2), 435-444. https://doi.org/10.2307/2525757

Msuya, E., \& Ashimogo, G. (2005). Estimation of Technical Efficiency in Tanzanian Sugarcane Production: A Case Study of Mtibwa Sugar Estate Outgrowers Scheme. Mpra Paper.

Mustapha, N. H. N. (2011). Technical efficiency for rubber smallholders under RISDA's supervisory system using stochastic frontier analysis. Journal of Sustainability Science and Management, 6(1), 156-168.

Poungchompu, S., \& Chantanop, S. (2015). Factor Affecting Technical Efficiency of Smallholder Rubber Farming in Northeast Thailand. American Journal of Agricultural and Biological Sciences, $10(2), 83$. https://doi.org/10.3844/ajabssp.2015.83.90

Sepien, A. B. (1979). Effects of some management proxies and sociological factors on productivity of rubber small holdings in Malaysia. South Aisian Studies, 17(1).

Son, T. V. H., Coelli, T., \& Fleming, E. (1993). Analysis of the technical efficiency of state rubber farms in Vietnam. Agricultural Economics, 9(3), 183-201. https://doi.org/10.1016/0169-5150(93)90047-g

Stevenson, R. E. (1980). Likelihood functions for generalized stochastic frontier estimation. Journal of Econometrics, 13(1), 57-66. https://doi.org/10.1016/0304-4076(80)90042-1

Taylor, T. G., \& Shonkwiler, J. S. (1986). Alternative stochastic specifications of the frontier production function in the analysis of agricultural credit programs and technical efficiency. Journal of Development Economics, 21(1), 149-160. https://doi.org/10.1016/0304-3878(86)90044-1

Tyler, W. G., \& Lee, L. F. (1979). On Estimating Stochastic Frontier Production Functions and Average Efficiency: An Empirical Analysis with Columbian Micro Data. The Review of Economics and Statistics, 436-438. https://doi.org/10.2307/1926074

\section{Copyrights}

Copyright for this article is retained by the author(s), with first publication rights granted to the journal.

This is an open-access article distributed under the terms and conditions of the Creative Commons Attribution license (http://creativecommons.org/licenses/by/4.0/). 